\title{
PFLP-Intensified Disease Resistance Against Bacterial Soft Rot Through the MAPK Pathway in PAMP-Triggered Immunity
}

\author{
Chuan-Yu Hong, Jing-Lin Zheng, Tzu-Yi Chen, How-Ran Chao, and Yi-Hsien Lin ${ }^{\dagger}$
}

First, second, third, and fifth authors: Department of Plant Medicine, and fourth author: Department of Environmental Science and Engineering, National Pingtung University of Science and Technology, Pingtung, Taiwan. Accepted for publication 2 July 2018.

\begin{abstract}
Bacterial soft rot is a devastating disease affecting a variety of vegetable crops worldwide. One strategy for controlling this disease could be the ectopic expression of the plant ferredoxin-like protein ( $p f l p)$ gene. PFLP was previously shown to intensify pathogen-associated molecular pattern-triggered immunity (PTI), an immune response triggered, for example, by the flagellin epitope flg22. To gain further insight into how PFLP intensifies PTI, flg22 was used as an elicitor in Arabidopsis thaliana. First, PFLP was confirmed to intensify the rapid generation of $\mathrm{H}_{2} \mathrm{O}_{2}$, callose deposition, and the hypersensitive response when coinfiltrated with flg22. This response correlated with increased

expression of the FLG22-induced receptor kinase 1 gene, which is part of the mitogen-activated protein kinase (MAPK) pathway. Although the increased response to flg22 alone did not depend on the MAPK pathway genes MEKK1, MKK5, and MPK6, the protective effect of PFLP decreased when plants mutated in these genes were inoculated with Pectobacterium carotovorum subsp. carotovorum. Furthermore, expression of PR1 and PDF1.2 also increased upon treatment with flg22 in the presence of PFLP. Taken together, these results suggest that activation of the MAPK pathway contributes to the increased resistance to bacterial soft rot observed in plants treated with PFLP.
\end{abstract}

Bacterial soft rot disease caused by Pectobacterium carotovorum subsp. carotovorum is a limiting factor in vegetable production worldwide (Pérombelon and Kelman 1980). This bacterium produces large quantities of pectic enzymes to macerate the tissues of vegetables and ornamental plants (Hauben et al. 1998; Pérombelon and Kelman 1980). To control bacterial soft rot, transgenic plants that express a plant ferredoxin-like protein ( $p f l p)$ gene are resistant to this disease. The PFLP-mediated resistance has been demonstrated in tobacco (Nicotiana tabacum), Arabidopsis thaliana, tomato (Solanum lycopersicum), calla lily (Zantedeschia elliottiana), and Oncidium orchids (Huang et al. 2004, 2007; Liau et al. 2003; Su et al. 2014; Yip et al. 2007). The resistance associated with the reactive oxygen species (ROS) generation and hypersensitive response (HR) triggered by pathogen elicitors such as harpin from Pseudomonas syringae pv. syringae is intensified by PFLP (Dayakar et al. 2003; Lin et al. 2010, 2011). Harpin, flagellin, peptidoglycan, and elongation factor Tu are pathogen-associated molecular patterns (PAMP) found in plant-pathogenic bacteria that are recognized by distinct specific receptors outside plant cells to trigger PAMP-triggered immunity (PTI) (Gust et al. 2007; Oh and Beer 2005; Postel and Kemmerling 2009). However, a report indicates that HR responses induced by harpin are similar to the responses of effector-triggered immunity based on the observation of cytoskeleton disruption (Guan et al. 2013). To clarify whether the PFLP-mediated disease resistance is associated with the enhancement of PTI, the flagellin from Pectobacterium carotovorum subsp. carotovorum was used to demonstrate that PFLP confers disease resistance through intensifying PTI responses (Su et al. 2014).

${ }^{\dagger}$ Corresponding author: Yi-Hsien Lin; E-mail: yhlin@mail.npust.edu.tw

Funding: This work was supported by grants to Dr. Yi-Hsien Lin from the Ministry of Science and Technology, Taiwan (MOST-104-2311-B-020-001 and MOST 1052628-B-020-002-MY3).

C.-Y. Hong and J.-L. Zheng contributed equally to this work.

(C) 2018 The American Phytopathological Society
PTI is a plant innate defense response triggered by the recognition of PAMP recognized by pattern recognition receptors (PRR) on the plasma membrane of host plant cells to further activate defense pathways (Dodds and Rathjen 2010). In the example of flagellin, this protein is the bacterial surface structure for motility. On flagellin, flg22 is the fragment which consisted of the most conserved 22 amino acid residues at the N-terminal region (Felix et al. 1999). The flg22 specifically binds to the leucine-rich repeat domain of a PRR on plant cell membranes such as flagellin-sensing 2 (FLS2) found in Arabidopsis thaliana (Chinchilla et al. 2006; Gómez-Gómez and Boller 2002). This recognition further induces defense pathways such as $\mathrm{Ca}^{2+}$ influx, rapid ROS generation, and the activation of calciumdependent protein kinase and mitogen-activated protein kinase (MAPK) pathways (Ali and Reddy 2008; Boudsocq et al. 2010; Monaghan and Zipfel 2012; Segonzac and Zipfel 2011). Moreover, the activation of the MAPK cascade (MEKK1, MKK4/MKK5, and MPK3/MPK6) induced by flg22 is regarded as a key factor for further conferring resistance against plant pathogens (Asai et al. 2002). Therefore, the intensification of PTI to enhance disease resistance may be associated with the activation of the MAPK cascade.

In this study, we sought to clarify whether PFLP-intensified disease resistance was due to the activation of a PTI-mediated MAPK pathway. The flg22 $2_{\text {Pst }}$ from Pseudomonas syringae pv. tabaci was used as an elicitor (Felix et al. 1999). In the flg22-triggering defense response, induction of the FLG22-induced receptor kinase 1 (FRK1) gene is specific to the activation of MAPK pathways (Asai et al. 2002; Boudsocq et al. 2010). Thus, the expression of FRK1 induced by flg22 ${ }_{\text {Pst }}$ upon treatment with PFLP was assayed. To further realize the role of MAPK pathways in PFLP-mediated disease resistance, resistance to bacterial soft rot disease intensified by PFLP on MAPK mutants of $A$. thaliana was evaluated.

\section{MATERIALS AND METHODS}

Growth conditions of plants and bacteria. A. thaliana ecotype Columbia (Col-0), a transgenic Arabidopsis ESF plant which overexpressed the extracellular PFLP (Lin et al. 2010), the mekk1 mutant (SALK_069473C), the $m k k 5$ mutant (SALK_047797C), 
and the mpk6 mutant (SALK_062471C) were used in this study. The plants were grown in a growth chamber (Hipoint) at $22^{\circ} \mathrm{C}$ with $16 \mathrm{~h}$ of light and $8 \mathrm{~h}$ of darkness. The 4 -week-old plants were used as materials to analyze plant immune responses, gene expression, and pathogen challenge. The soft rot bacterium Pectobacterium carotovorum subsp. carotovorum Ecc 17 was used in the inoculation

TABLE 1. Quantitative real-time polymerase chain reaction primers used in this study

\begin{tabular}{|c|c|c|}
\hline Gene & Sequence $\left(5^{\prime}-3^{\prime}\right)$ & Reference \\
\hline FRK1 & $\begin{array}{l}\text { F: CGGTCAGATTTCAACAGTTGTC } \\
\text { R: AATAGCAGGTTGGCCTGTAATC }\end{array}$ & Boudsocq et al. 2010 \\
\hline МРКб & $\begin{array}{l}\text { F: GCGGCTCCATCGCCTCAGAT } \\
\text { R: ACGATGCCATAAGCACCCTTGC }\end{array}$ & Kannan et al. 2012 \\
\hline PR1 & $\begin{array}{l}\text { F: TTCTTCCCTCGAAGCTCAA } \\
\text { R: AAGGCCCACCAGAGTGTATG }\end{array}$ & Göhre et al. 2012 \\
\hline PDF 1.2 & $\begin{array}{l}\text { F: TTGCTGCTTTCGACGCA } \\
\text { R: TGTCCCACTTGGCTTCTCG }\end{array}$ & Brown et al. 2003 \\
\hline TUB4 & $\begin{array}{l}\text { F: AGGGAAACGAAGACAGCAAG } \\
\text { R: GCTCGCTAATCCTACCTTTGG }\end{array}$ & Boudsocq et al. 2010 \\
\hline
\end{tabular}

assay. Before inoculation, Ecc17 was transferred on a nutrient broth agar plate and incubated at $28^{\circ} \mathrm{C}$ for $48 \mathrm{~h}$.

Preparation of flg22 $2_{\text {Pst }}$ and PFLP. In this study, flg22 $2_{\mathrm{Pst}}$ (TRLSSGLKINSAKDDAAGLQIA) from Pseudomonas syringae pv. tabaci was synthesized by LifeTein LLC. The synthesized flg22 $2_{\mathrm{Pst}}$ was prepared in $25 \mathrm{mM}$ Tris-HCl buffer $(\mathrm{pH} 7.5)$ at $5 \mathrm{mM}$ before assay. PFLP was obtained from Escherichia coli (Lin et al. 2011). Briefly, the crude extract of recombinant protein was purified in a column containing Ni-NTA (GE Healthcare). Subsequently, the eluted protein was desalted with a centrifugal filter tube (Amicon Ultra). Finally, the purified PFLP was dissolved in $25 \mathrm{mM}$ Tris- $\mathrm{HCl}$ buffer.

HR assay. Our previous studies showed that the strength of weak defense responses triggered by PAMP was intensified by PFLP to achieve the occurrence of HR postinfiltration (Dayakar et al. 2003; Lin et al. 2010, 2011; Su et al. 2014). To assess whether the HR could be induced by coinfiltrating of PFLP and flg22 $2_{\mathrm{Pst}}$, mixtures of PFLP and flg22 $2_{\text {Pst }}$ were prepared at $0.5 \mathrm{mg} / \mathrm{ml}$ and $0.5 \mu \mathrm{M}$, respectively. The mixture was then assayed on Arabidopsis plants following the previously described protocol (Lin et al. 2010).
A

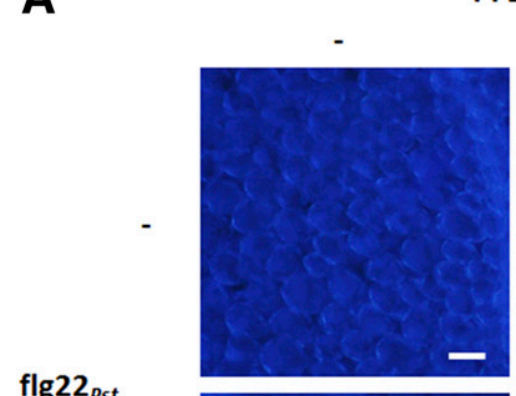

flg22 $p_{s t}$

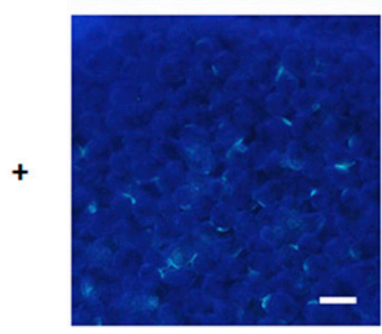

C

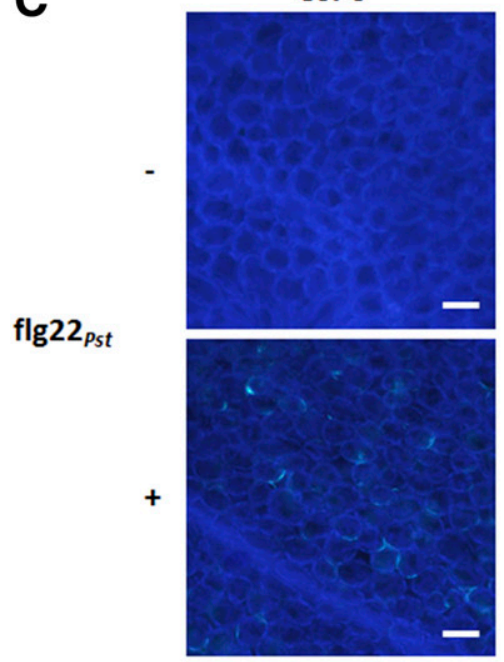

PFLP

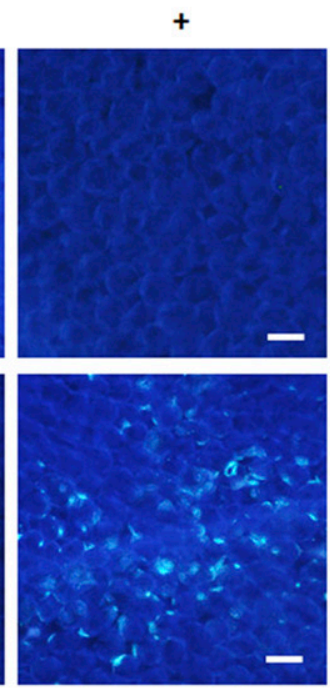

ESF

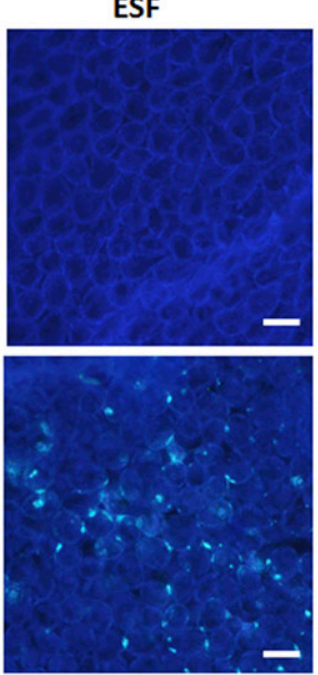

B
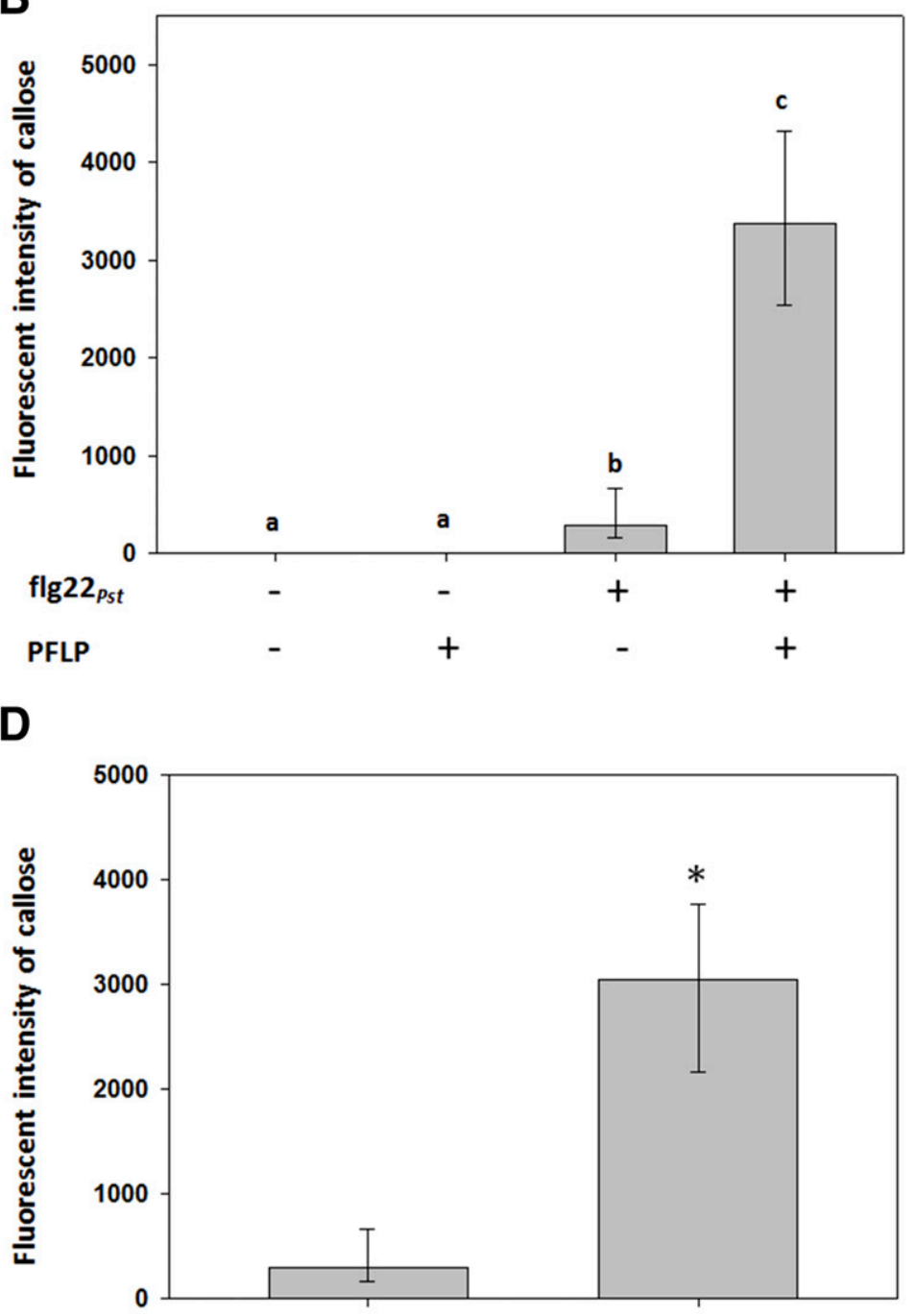

Col-0
ESF

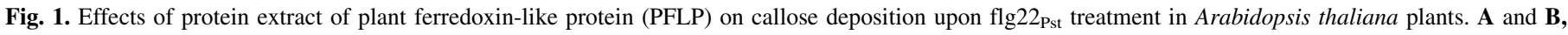

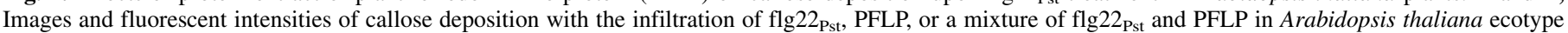

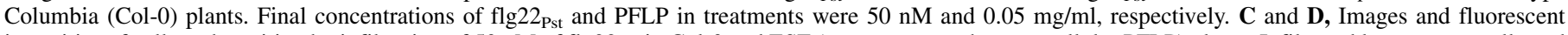

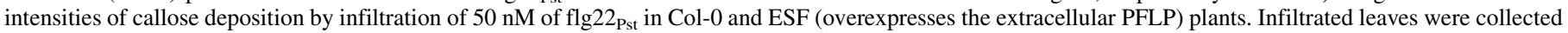

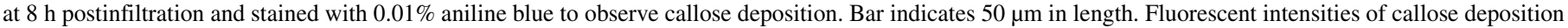
were counted by ImageJ. Different letters above the bars indicate significant differences according to Tukey's honestly significant difference test $(P<0.05)$. 
Similarly, infiltration carried out with six inoculation sites in one plant was regarded as one repeat. The HR ratio was calculated as $(\mathrm{Nn} / 6) \times 100 \%$ at $24 \mathrm{~h}$ postinfiltration, where $\mathrm{Nn}$ is the number of inoculation sites with HR necrosis. Thirty plants were assayed as replications in one assay.

Callose staining. To observe callose deposition, the infiltrated Arabidopsis leaves were collected at $8 \mathrm{~h}$ postinfiltration. Leaf infiltration was performed with flg22 $2_{\text {Pst }}$ and PFLP at $50 \mathrm{nM}$ and $0.05 \mathrm{mg} / \mathrm{ml}$, respectively. Control plants were infiltrated with $25 \mathrm{mM}$ Tris- $\mathrm{HCl}$ (pH 7.5) or PFLP at $0.05 \mathrm{mg} / \mathrm{ml}$ alone. The collected leaves were soaked in $95 \%$ ethanol overnight and further stained with $0.01 \%$ aniline blue (Sigma-Aldrich) in $0.1 \mathrm{M}$ phosphate buffer ( $\mathrm{pH} 8$ ) for $2 \mathrm{~h}$. Callose deposition was observed under a fluorescence microscope filter set (Leica) with an excitation at 340 to $380 \mathrm{~nm}$ and an emission at 400 to $425 \mathrm{~nm}$. The strength of callose deposition was determined using the Image J software (https://imagej.nih.gov/ij/) to measure the fluorescent intensity under a consistent threshold (Rasband 19972016). Each value was collected from 10 samples of individual leaves in each treatment as repeated. The data were analyzed by Tukey's honestly significant difference test at a 5\% significance level.

Quantitative real-time polymerase chain reaction. To monitor the changes in gene expression levels, the infiltrated Arabidopsis leaves were collected at $0,0.5,4$, and $24 \mathrm{~h}$ postinfiltration. The infiltration of flg22 $2_{\text {Pst }}$ and PFLP was carried out at $0.5 \mu \mathrm{M}$ and $0.5 \mathrm{mg} / \mathrm{ml}$, respectively. Total RNA was extracted from collected infiltrated leaves using a Total RNA Mini Kit (Geneaid). Total RNA $(1 \mu \mathrm{g})$ was used to synthesize the cDNA with the Transcriptor FirstStrand cDNA Synthesis Kit (Roche). Quantitative real-time polymerase chain reaction (PCR) was performed with $200 \mathrm{ng}$ of cDNA and $500 \mathrm{nM}$ each gene-specific primer in iQ SYBR Green supermix reagent (Bio-Rad). Specific primers for quantitative real-time PCR shown in Table 1 were used, and the program was performed as follows: $95^{\circ} \mathrm{C}$ for $3 \mathrm{~min}$, followed by 35 cycles of $95^{\circ} \mathrm{C}$ for $10 \mathrm{~s}$ and $50^{\circ} \mathrm{C}$ for $30 \mathrm{~s}$. Analysis of the melting curve was conducted to identify the specificity of products. The expression of TUB4 was used as a reference gene, and data were analyzed using CFX Manager 3.0 (Bio$\mathrm{Rad})$. The fold induction of each treatment was normalized by mock treatment at $0 \mathrm{~h}$ postinfiltration. At least nine samples of each treatment were analyzed as replicates in this assay.

Disease severity assay. Bacterial soft rot disease was assayed in Arabidopsis plants. Before inoculation, bacterial suspension of Ecc17 was prepared to an optical density at $600 \mathrm{~nm}$ of $0.3\left(10^{8} \mathrm{CFU} /\right.$ $\mathrm{ml})$. The 100-fold dilution of bacterial suspension $\left(10^{6} \mathrm{CFU} / \mathrm{ml}\right)$ was prepared as an inoculating suspension. Inoculation was performed by infiltrating with a mixture of the inoculating suspension and PFLP at $1 \mathrm{mg} / \mathrm{ml}$ at equal volume. The infiltrated plants were incubated in a growth chamber at $25^{\circ} \mathrm{C}$ for $24 \mathrm{~h}$. The indexes of soft rot symptoms were rated from 0 to $4(0=$ no symptom, $1=$ watery or soft rot area ratio of 0 to $25 \%, 2=$ soft rot area ratio of 25 to $50 \%, 3=$ soft rot area ratio of 50 to $75 \%$, and $4=$ soft rot area ratio of 75 to $100 \%)$. The total number $(N)$ of leaves was then counted with the rated indexes. The disease severity for each trial was calculated with the following formula: $\left[\left(0 \times N_{0}+1 \times N_{1}+\right.\right.$ $\left.\left.2 \times N_{2}+3 \times N_{3}+4 \times N_{4}\right) /(4 \times N)\right] \times 100 \%$. Each disease severity was collected from one plant as one repeat, and nine repeats were performed for statistical analysis in this assay.

\section{RESULTS}

Callose deposition induced by flg22 $_{\text {Pst }}$ in Arabidopsis plants. The callose deposition induced by flg $22_{\text {Pst }}$ was observed at $8 \mathrm{~h}$ postinfiltration. Among the results, fluorescent signals indicating callose deposition were induced by flg $22_{\text {Pst }}$ surrounding the cells in Col- 0 plants. Furthermore, more abundant callose deposition was observed in the infiltration with the mixture of flg22 $2_{\text {Pst }}$ and PFLP recombinant protein (Fig. 1A). Compared with the treatment with flg22 $2_{\text {Pst }}$ alone, the fluorescent intensity was increased by 8.3 -fold in the treatment with flg22 $2_{\text {Pst }}$ and PFLP (Fig.
1B). No signals were observed in the blank treatment or that with PFLP recombinant protein alone. To observe the callose signals induced by flg22 $2_{\text {Pst }}$ in transgenic plants with PFLP, ESF plants were assayed. The results indicated that abundant callose deposition was induced by flg22 $2_{\text {Pst }}$ in ESF plants (Fig. 1C). The fluorescent intensity triggered by flg22 $2_{\mathrm{Pst}}$ in the ESF plant was 7.1-fold higher than that in the Col-0 plant (Fig. 1D). However, in ESF plants (similar to what occurred in Col-0 plants), no callose deposition was observed in the infiltrations without flg22 $2_{\text {Pst }}$.

HR induced by flg22 $2_{\text {st }}$ in Arabidopsis plants. To clarify whether or not the PTI was intensified by PFLP in A. thaliana, the HR was evaluated by infiltrating flg $22_{\mathrm{Pst}}$ as a PAMP. Compared with the negative control, PFLP or flg $22_{\mathrm{Pst}}$ alone did not induce the HR response (Fig. 2A). However, an HR ratio was significantly induced by the mixture of PFLP and flg $22_{\mathrm{Pst}}$. Compared with the results in ESF plants, the HR ratio was induced more strongly by flg22 $2_{\text {Pst }}$ than that by the blank treatment (Fig. 2B).

Expression of FRK1 gene in flg22 2 st-induced response intensified by PFLP. In order to clarify the role of PFLP in the activation of MAPK pathways induced by flg22 $2_{\mathrm{Pst}}$, the expression of the FRK1 gene was monitored in Col- 0 plants after infiltration. Compared with the blank treatment, $F R K 1$ was not induced by
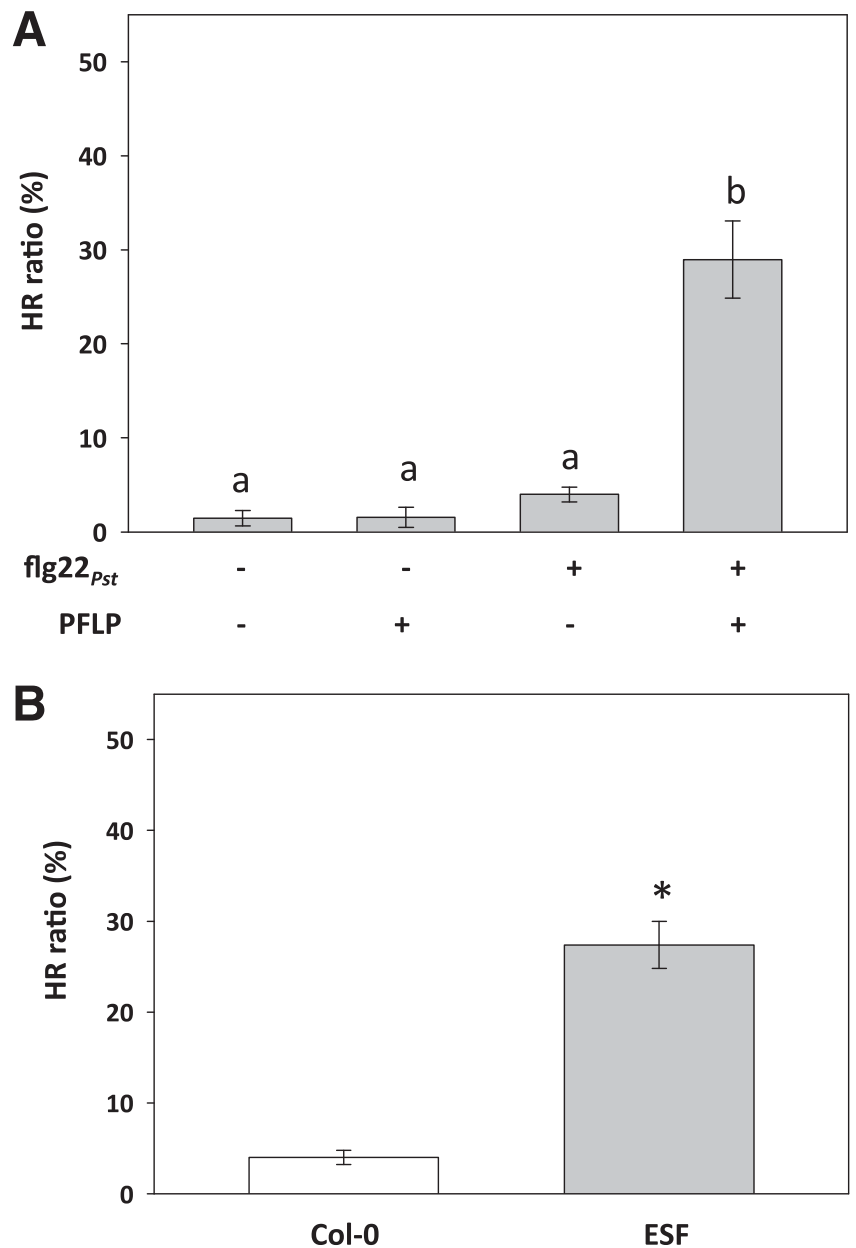

Fig. 2. Effects of protein extract of plant ferredoxin-like protein (PFLP) on flg2 $22_{\mathrm{Pst}}$-induced hypersensitive response (HR) in Arabidopsis plants. A, HR induced by infiltration with flg22 $2_{\text {Pst }}$, PFLP, or mixture of flg22 $2_{\text {st }}$ and PFLP in Col-0 plants. B, HR induced by infiltration with $0.5 \mu \mathrm{M}$ flg $22_{\mathrm{Pst}}$ in Arabidopsis Col-0 and ESF plants. Final concentrations of flg22 ${ }_{\text {Pst }}$ and PFLP in treatments were $0.5 \mu \mathrm{M}$ and $0.5 \mathrm{mg} / \mathrm{ml}$, respectively. HR ratios in Arabidopsis plants were recorded at $24 \mathrm{~h}$ postinfiltration. More than 30 plants of each treatment were analyzed as replicates in this assay. Different letters indicated significant differences between treatments based on Tukey's honestly significant difference test $(P<0.05)$, and an asterisk indicates significant differences based on a $t$ test $(P<0.05)$. 
flg $22_{\text {Pst }}$ or by the treatment with flg22 $2_{\text {Pst }}$ combined with PFLP (i.e., the mixture) at $0.5 \mathrm{~h}$ postinfiltration. At 4 and $24 \mathrm{~h}$ postinfiltration, the relative expression levels of $F R K 1$ induced by flg22 $2_{\text {Pst }}$ were 19.7- and 26.2-fold, respectively. This induction at 4 and $24 \mathrm{~h}$ postinfiltration was significantly increased by PFLP to 42.1- and 68.6-fold, respectively (Fig. 3A). Compared with the blank treatment, MPK6 was not induced by flg $22_{\mathrm{Pst}}$ or by flg22 2 combined with PFLP at 0.5 and $4 \mathrm{~h}$ postinfiltration. At $24 \mathrm{~h}$ postinfiltration, however, the relative expression levels of MPK6 were significantly induced by the flg22 $\mathrm{Pst}$ and the mixture to 2.7 and 2.9-fold, respectively. In addition, PFLP did not increase the expression level of MPK6 at $24 \mathrm{~h}$ postinfiltration (Fig. 3B).
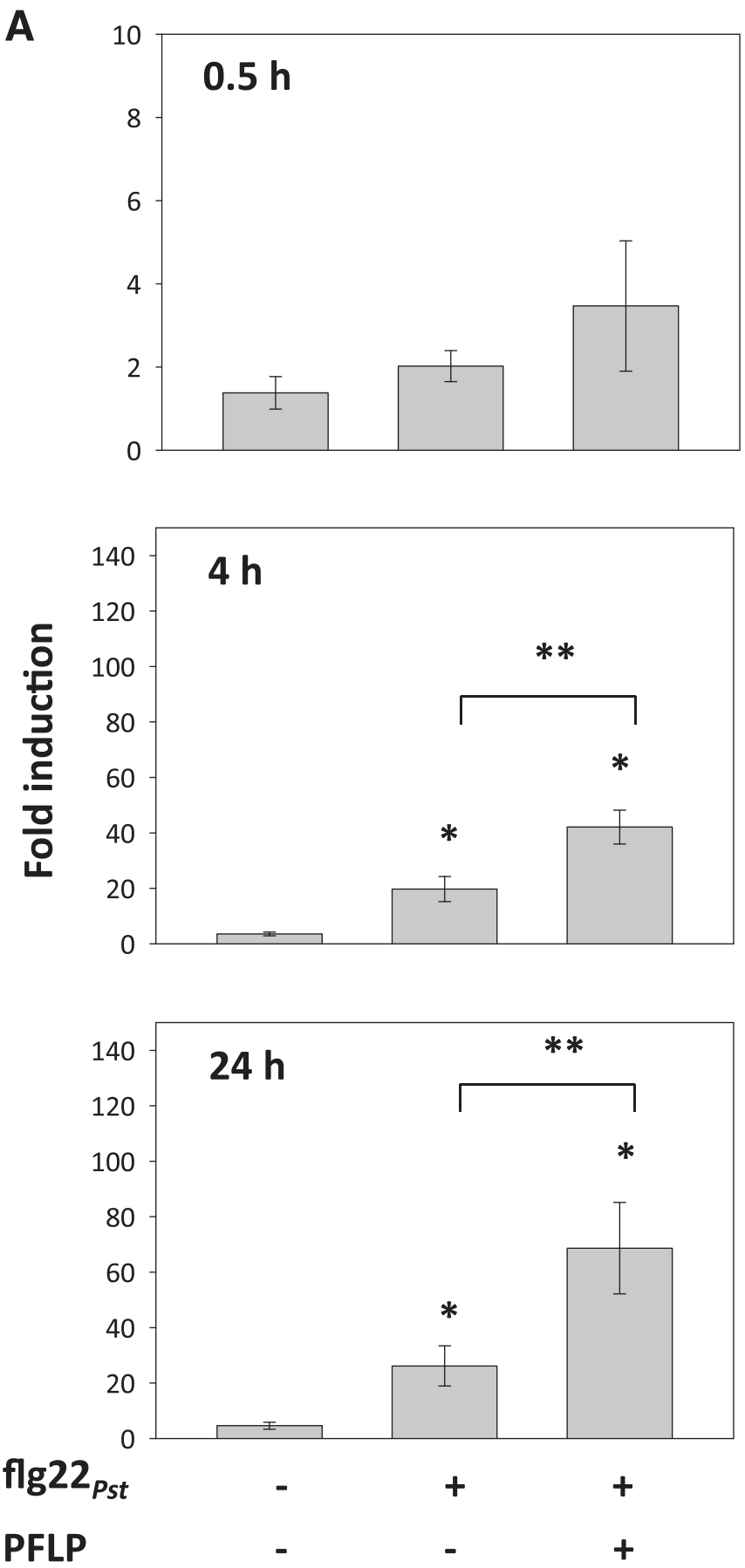

PFLP-intensified disease resistance in Arabidopsis mutants. To assess whether the PFLP still intensified resistance to bacterial soft rot in Arabidopsis mutants via the MAPK pathway, the disease severities caused by Pectobacterium carotovorum subsp. carotovorum Ecc17 were evaluated on mekk1, mkk5, and mpk6 plants. The results indicated that the disease severity on Col-0 plants was reduced from 56.6 to $16.7 \%$ by PFLP. Compared with the severe soft rot symptoms on inoculated leaves, most leaves were symptomless in the treatment with PFLP at $24 \mathrm{~h}$ postinoculation. However, the intensification of disease resistance against bacterial soft rot by PFLP was abolished in mekkl (49.6\%), $m k k 5$ (53.1\%), and $m p k 6$ (48.9\%) plants (Fig. 4).
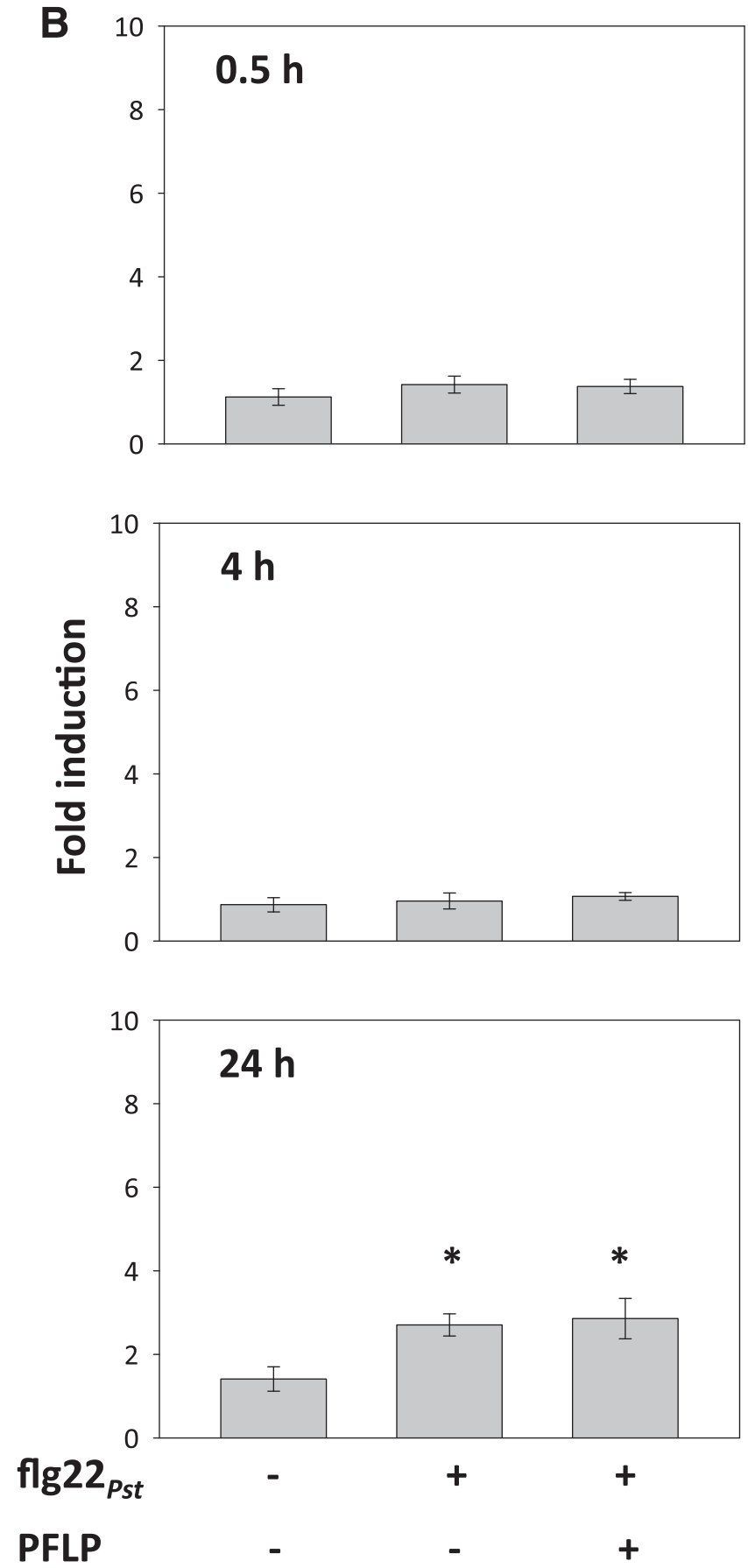

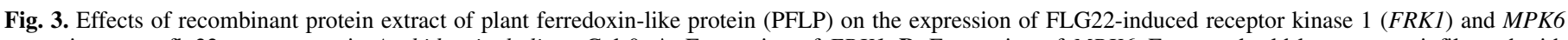

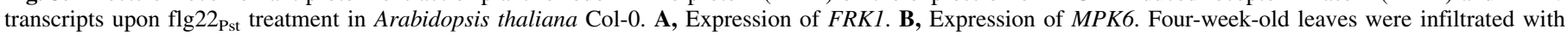

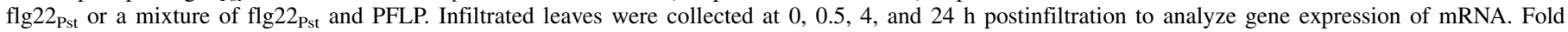

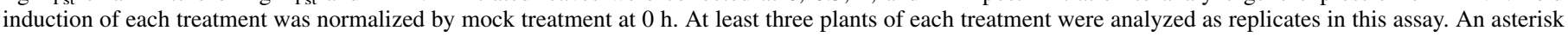

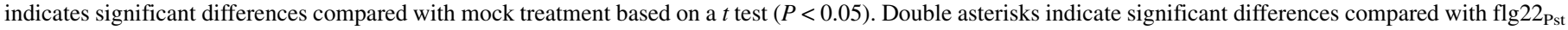
treatments based on a $t$ test $(P<0.05)$. 


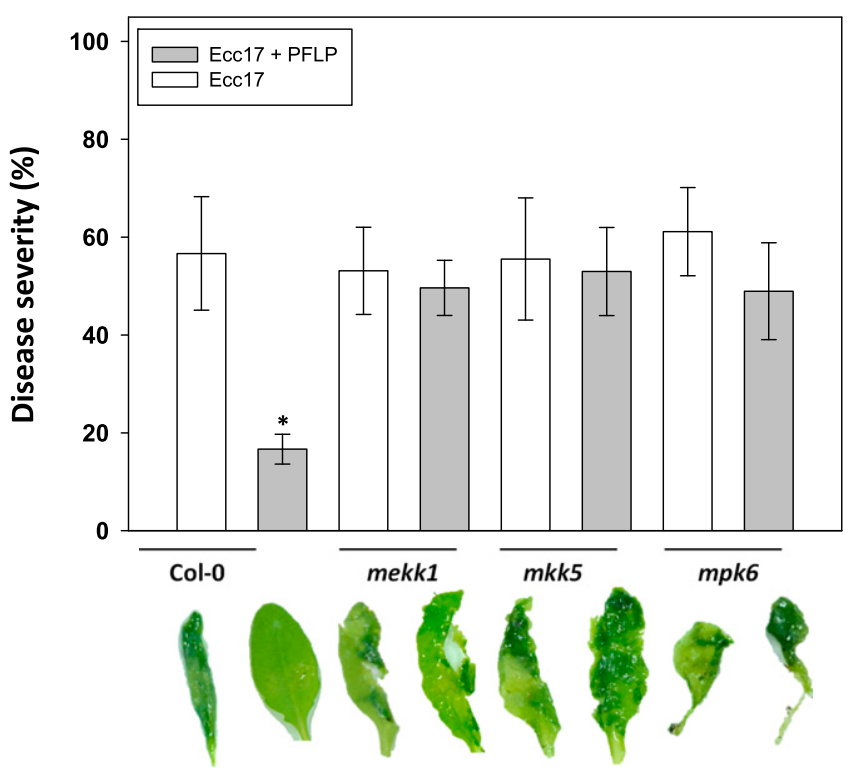

Fig. 4. Effects of protein extract of plant ferredoxin-like protein (PFLP) against bacterial soft rot in Arabidopsis mutants. Leaves of 4-week-old mekkl, $m k k 5$, and mpk6 plants were infiltrated with Pectobacterium carotovorum subsp. carotovorum Ecc17 at $10^{6} \mathrm{CFU} / \mathrm{ml}$ as a control. Experiments were carried out with the mixture of Ecc17 and PFLP at $10^{6} \mathrm{CFU} / \mathrm{ml}$ and $1 \mathrm{mg} / \mathrm{ml}$, respectively. Infiltrated leaves were observed at $24 \mathrm{~h}$ postinfiltration to analyze disease severity. At least nine infiltrated leaves of each treatment were analyzed as replicates in this assay. An asterisk indicates significant differences based on a $t$ test $(P<0.05)$.
PFLP-intensified callose deposition in Arabidopsis mutants. To ascertain whether the PFLP-intensified callose deposition was affected by the MAPK pathway, it was also observed in mekk1, mkk5, and mpk6 mutants. The results indicated that the callose signals were induced by the infiltration of flg22 2 around the cells of these mutants (Fig. 5A). The fluorescent intensities of callose deposition induced by flg $22_{\mathrm{Pst}}$ were intensified by PFLP to 5.5-, 6.5-, and 6.6-fold in mekk1, mekk5, and mpk6 mutants, respectively (Fig. 5B).

PFLP-intensified defense signals in salicylic acid and ethylene/jasmonate pathways. In order to further understand the association between PFLP-mediated disease resistance and signals in induced resistance, the expression of the pathogenesisrelated $1(P R 1)$ gene in the salicylic acid pathway and PDF1.2 gene in the ethylene/jasmonate pathway were evaluated. In the salicylic acid pathway, $P R 1$ was not induced by the treatment with flg22 $2_{\mathrm{Pst}}$ or by the treatment with flg22 $2_{\text {Pst }}$ combined with PFLP (i.e., the mixture) at 0.5 and $4 \mathrm{~h}$ postinfiltration. However, the relative expression level of $P R 1$ was induced by flg22 2 to 104.5 -fold and was strongly intensified by PFLP to $1,066.5$-fold at $24 \mathrm{~h}$ postinfiltration (Fig. 6A). In the ethylene/jasmonate pathway, the relative expression levels of the $P D F 1.2$ gene were significantly induced by flg $22_{\mathrm{Pst}}$ at $0.5,4$, and $24 \mathrm{~h}$ postinfiltration. Similarly, it was significantly intensified by PFLP to 10.1 -fold at $24 \mathrm{~h}$ postinfiltration (Fig. 6B).

\section{DISCUSSION}

The fact that PFLP enhances disease resistance against bacterial diseases was well documented (Ger et al. 2014; Huang et al. 2007; Liau et al. 2003; Lin et al. 2010, 2011; Namukwaya et al. 2012; Tang et al. 2001; Yip et al. 2007). Our previous study showed that the
A
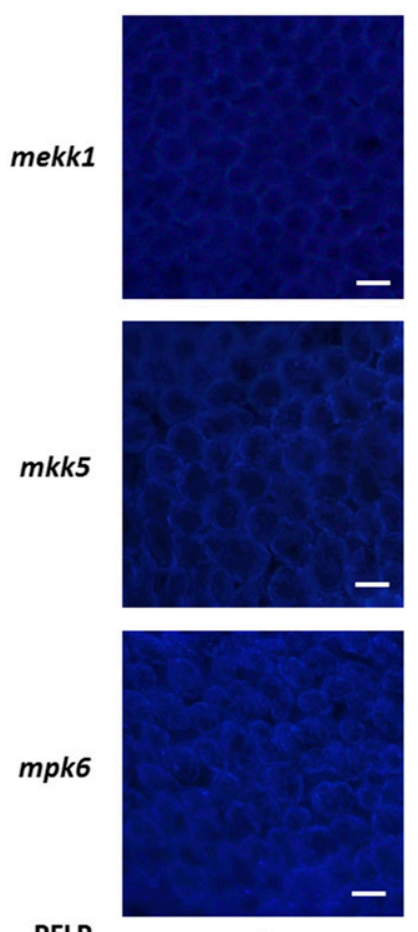

PFLP

flg22 ${ }_{P_{s t}}$
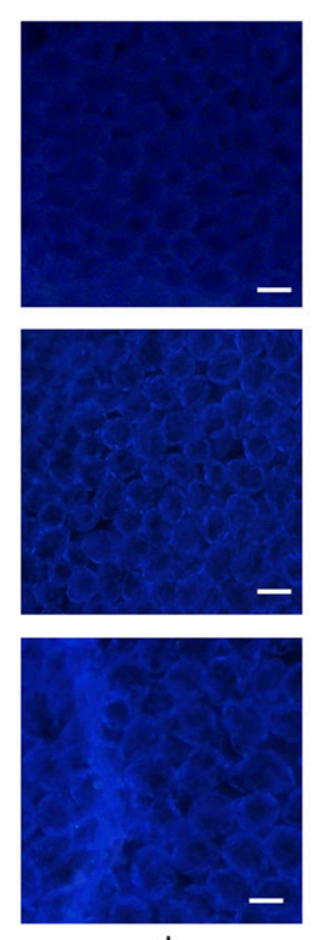

$+$

$-$
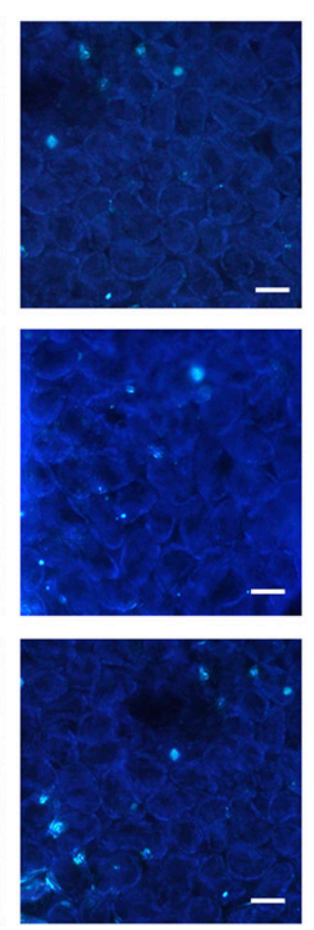

$-$

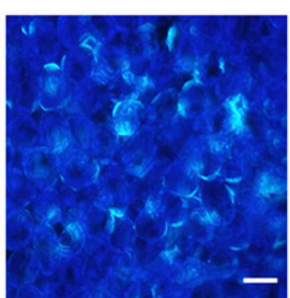

B
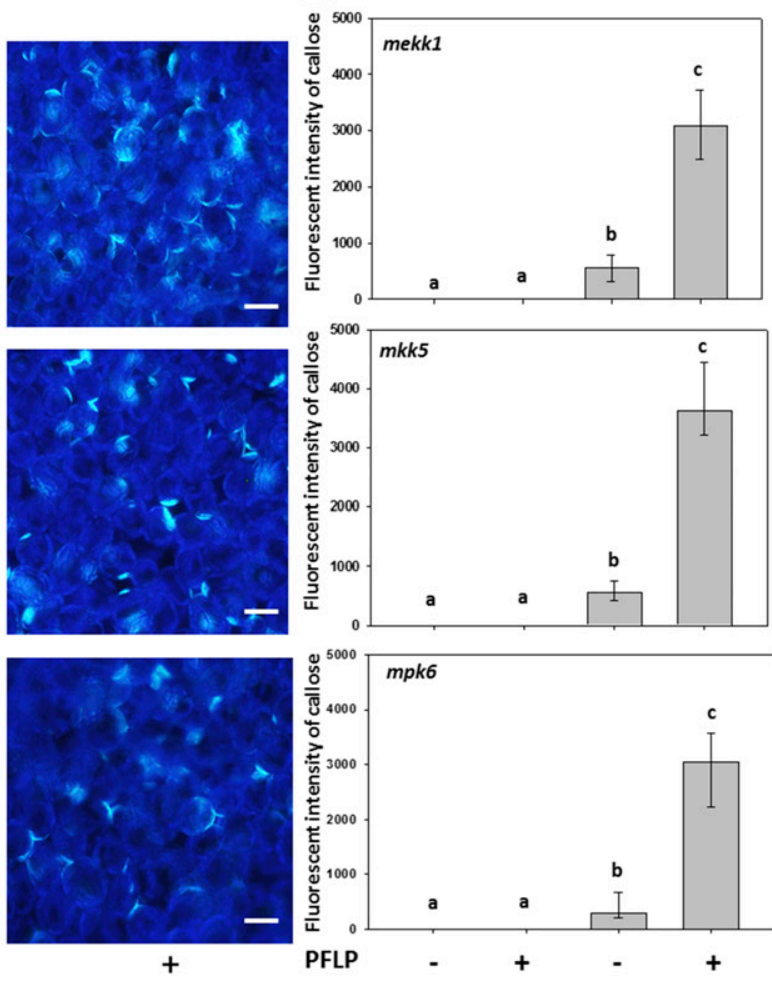

$+$

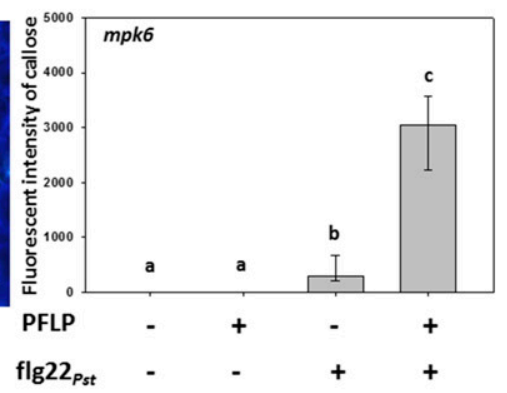

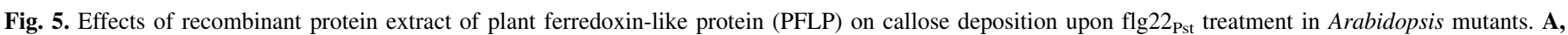
Callose deposition was performed with the infiltration of flg22 Pst, PFLP, or the mixture of flg22 $2_{\text {st }}$ and PFLP in mekk1, mkk5, and $m p k 6$ plants. Infiltrated leaves were collected at $8 \mathrm{~h}$ postinfiltration and further stained with $0.01 \%$ aniline blue to observe callose deposition. Bar indicates $50 \mu \mathrm{m}$ in length. B, Fluorescent intensities of callose deposition count by ImageJ. Different letters above the bars indicate significantly different according to Tukey's honestly significant difference test $(P<0.05)$. 
enhanced disease resistance against bacterial soft rot may be associated with the PTI activated by flagellin (Su et al. 2014). Such activation of plant innate immune responses by flagellin is due to the fact that its conserved region, flg22, is recognized by FLS2 on the plasma membrane of plant cells (Chinchilla et al. 2006; Denoux et al. 2008; Monaghan and Zipfel 2012; Zipfel 2008). In this study, the callose deposition and HR ratio were increased by PFLP upon the infiltration of flg22 2 Pst . The results induced by flg22 $2_{\mathrm{Pst}}$ are similar to those induced with the flagellin from $P$. carotovorum subsp. carotovorum ( $\mathrm{Su}$ et al. 2014). Compared with the amino acid sequences of flg22 from various bacterial pathogens, the flg22s found in different genera of plant-pathogenic bacteria exhibit conservation of their sequences. In addition, the flg $22_{\mathrm{Pcc}}$ from
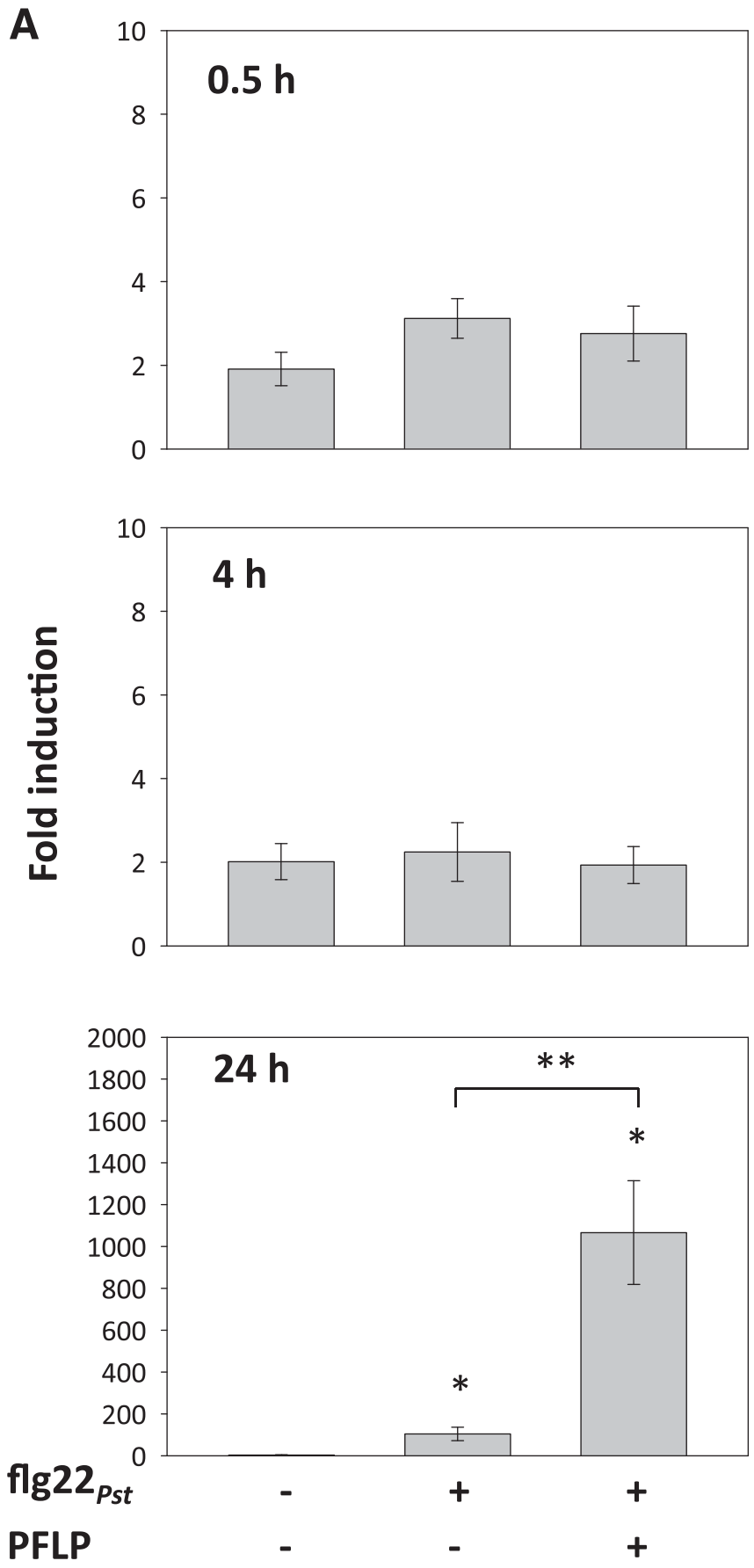

P. carotovorum subsp. carotovorum was shown to be $81.8 \%$ identical to the flg22 $2_{\mathrm{Pst}}$ from Pseudomonas syringae pv. tabaci (Fig. 7). Therefore, we suggest that the PTI triggered by flagellin could be intensified by PFLP.

The MAPK pathway is one of the main routes by which plant defense responses are activated during PTI (Ali and Reddy 2008; Asai et al. 2002; Denoux et al. 2008; Jones and Dangl 2006; Nicaise et al. 2009; Zhang and Zhou 2010). To demonstrate in greater detail how PFLP acts upon the MAPK pathway, the expression level of FRK1 was assayed as an indicator (Asai et al. 2002; Boudsocq et al. 2010). Here, we demonstrated that the expression of FRKl was induced by flg22 $2_{\mathrm{Pst}}$ and that this induction could be further intensified by PFLP. This increase in the expression level of FRKI is

B
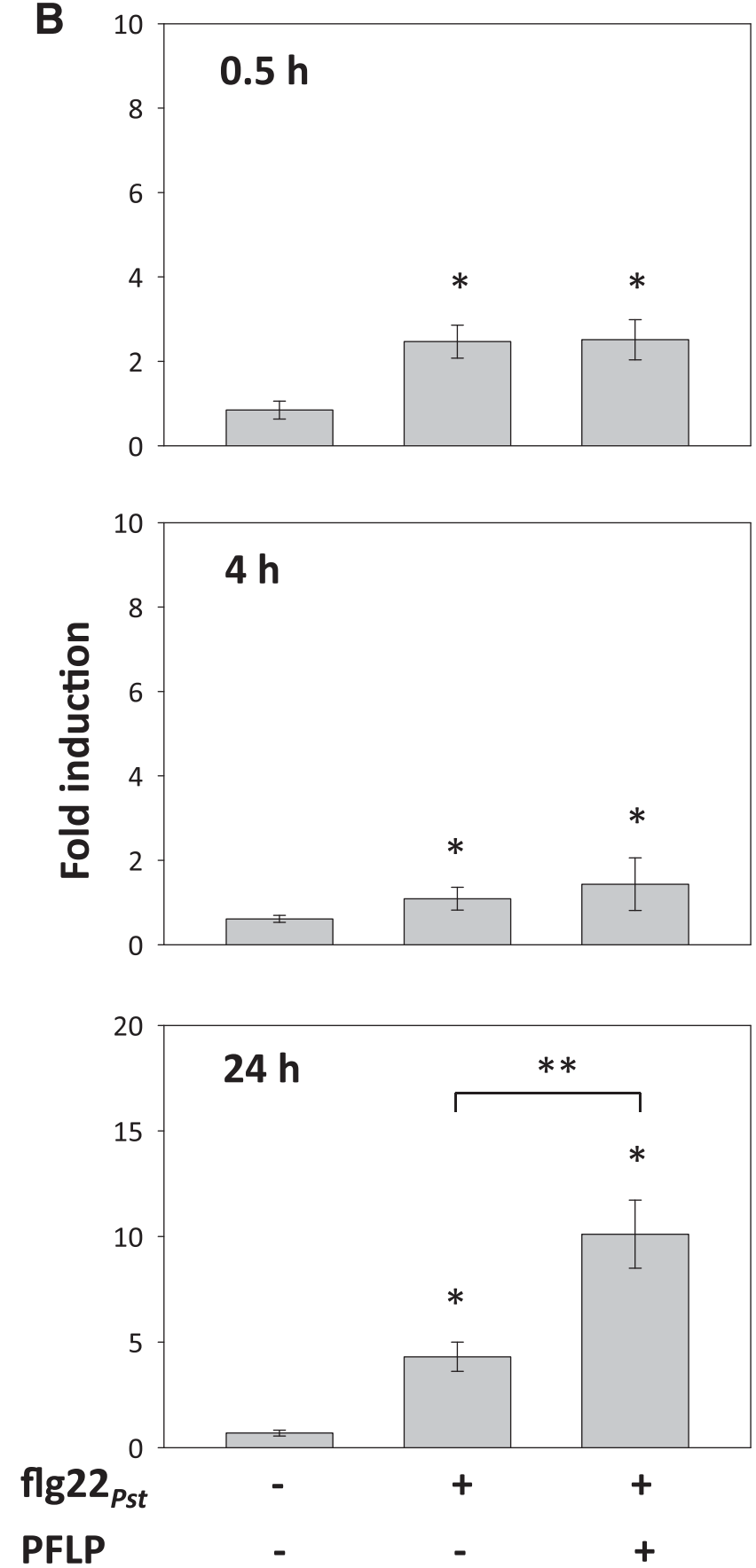

Fig. 6. Effects of recombinant protein extract of plant ferredoxin-like protein (PFLP) on the expression of PR1 and PDF1.2 transcripts upon flg22 $2_{\mathrm{Pst}}$ treatment in Arabidopsis thaliana Col-0. A, Expression of PR1. B, Expression of PDF1.2. Four-week-old leaves were infiltrated with flg22 $2_{\mathrm{Pst}}$ or a mixture of flg22 $2_{\mathrm{Pst}}$ and PFLP. Infiltrated leaves were collected at $0,0.5,4$, and $24 \mathrm{~h}$ postinfiltration to analyze gene expression of mRNA. Fold induction of each treatment was normalized by mock treatment at $0 \mathrm{~h}$. At least three plants of each treatment were analyzed as replicates in this assay. An asterisk indicates significant differences compared with mock treatment based on a $t$ test $(P<0.05)$. Double asterisks indicate significant differences compared with flg22 Pst treatments based on a $t$ test $(P<0.05)$. 


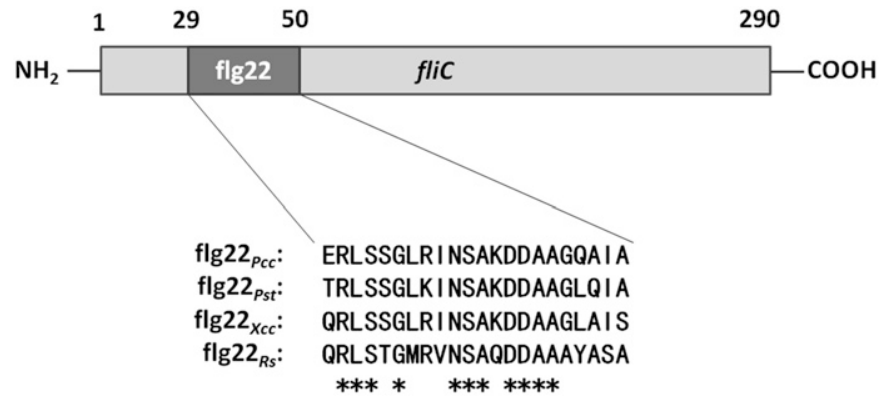

Fig. 7. Amino acid sequences of flg22 in flagellin of phytopathogenic bacteria. $P c c, P s t, X c c$, and Rs indicate Pectobacterium carotovorum subsp. carotovorum Ecc17 (JX261932), Pseudomonas syringae pv. tabaci 6605 (AB061230), Xanthomonas campestris pv. campestris B305 (DQ356465), and Ralstonia solanacearum (AF283285), respectively. Asterisks indicate the conserved sequences in these bacteria.

accompanied by the phosphorylation of MPK3/MPK6 by flg22 $2_{\text {Pst }}$ (Asai et al. 2002). However, PFLP did not intensify the expression level of MPK6 induced by flg22 $2_{\text {Pst }}$. Therefore, we suggest that PFLP may contribute to the intensification of signal transduction rather than to that of gene induction in the MAPK pathway.

The activation of the flg22-mediated MAPK pathway through the signaling of MEKK1-MKK4/MKK5-MPK3/MPK6 leads to the expression of defense genes (Ali and Reddy 2008; Asai et al. 2002; Muthamilarasan and Prasad 2013). In this study, the results indicated that the PFLP-mediated disease resistance against bacterial soft rot induced via the MAPK pathway was abolished in all Arabidopsis mutants. However, the flg22 $2_{\mathrm{Pst}}$-induced callose deposition was still intensified by PFLP in these mutants. Callose is accumulated during pathogen penetration on cell walls, and overexpression of its synthase in transgenic Arabidopsis results in successful suppression of the penetration of powdery mildew (Ellinger et al. 2013). However, the abundant callose deposition in $m e k k 1, m k k 5$, and $m p k 6$ mutants intensified by PFLP shown in this study did not evoke equivalent disease resistance against bacterial soft rot disease. This might be due to callose deposition acting as one of the independent defense responses activated in PTI (Eggert et al. 2014; Luna et al. 2011; Ma et al. 2016; Panstruga et al. 2009; Zipfel and Robatzek 2010). Thus, we further suggest that PFLP was able to intensify defense routes other than signal transduction through the MAPK pathway. Nevertheless, the degree to which disease resistance against fungal pathogens intensified by PFLP is still unknown and needs to be further investigated.

Plant immune responses are also regulated by small-hormone networks such as the salicylic acid and jasmonate/ethylene pathways (Eulgem and Somssich 2007; Pieterse et al. 2009; Torres 2010). Our results indicated that the expression of both PRI and PDF1.2 was induced by more than twofold by flg22 $2_{\text {Pst }}$ at $24 \mathrm{~h}$ postinfiltration, and this induction was strongly intensified by PFLP. Relatedly, our previous study showed that PFLP still intensified disease resistance in $n p r l$ and $N A H G$ plants (Ger et al. 2014). Compared with our inoculation results for MAPK mutants against bacterial soft rot, we suggest that the signals of the small hormones might be of secondary importance in this PFLP-mediated disease resistance.

Taken together, the results of this study lead us to conclude that the multiple PTI-triggered defense responses are intensified by PFLP. Most importantly, the results of this study demonstrate that the PFLP-intensified disease resistance against bacterial soft rot requires signal transduction through the MAPK pathway.

\section{LITERATURE CITED}

Ali, G. S., and Reddy, A. S. N. 2008. PAMP-triggered immunity. Plant Signal. Behav. 3:423-426.

Asai, T., Tena, G., Plotnikova, J., Willmann, M. R., Chiu, W. L., Gomez-Gomez, L., Boller, T., Ausubel, F. M., and Sheen, J. 2002. MAP kinase signaling cascade in Arabidopsis innate immunity. Nature 415: 977-983.

Boudsocq, M., Willmann, M. R., McCormack, M., Lee, H., Shan, L., He, P., Bush, J., Cheng, S. H., and Sheen, J. 2010. Differential innate immune signalling via $\mathrm{Ca}^{2+}$ sensor protein kinases. Nature 464:418-422.

Brown, R. L., Kazan, K., McGrath, K. C., Maclean, D. J., and Manners, J. M. 2003. A role for the GCC-box in jasmonate-mediated activation of the PDF1.2 gene of Arabidopsis. Plant Physiol. 132:1020-1032.

Chinchilla, D., Bauer, Z., Regenass, M., Boller, T., and Felix, G. 2006. The Arabidopsis receptor kinase FLS2 binds flg22 and determines the specificity of flagellin perception. Plant Cell 18:465-476.

Dayakar, B. V., Lin, H.-J., Chen, C.-H., Ger, M.-J., Lee, B.-H., Pai, C.-H., Chow, D., Huang, H.-E., Hwang, S.-Y., Chung, M.-C., and Feng, T.-Y. 2003. Ferredoxin from sweet pepper (Capsicum annuum L.) intensifying harpin $_{\mathrm{pss}}-$ mediated hypersensitive response shows an enhanced production of active oxygen species (AOS). Plant Mol. Biol. 51:913-924.

Denoux, G., Galletti, R., Mammarella, N., Gopalam, S., Werck, D., Lorenzo, G. D., Ferrari, S., Ausubel, F. M., and Dewdney, J. 2008. Activation of defense response pathways by OGs and Flg22 elicitors in Arabidopsis seedlings. Mol. Plant 1:423-445.

Dodds, P. N., and Rathjen, J. P. 2010. Plant immunity: Towards an integrated view of plant-pathogen interactions. Nat. Rev. Genet. 11:539-548.

Eggert, D., Naumann, M., Reimer, R., and Voigt, C. A. 2014. Nanoscale glucan polymer network causes pathogen resistance. Sci. Rep. 4: Article 4159 .

Ellinger, D., Naumann, M., Falter, C., Zwikowics, C., Jamrow, T., Manisseri, C., Somerville, S. C., and Voigt, C. A. 2013. Elevated early callose deposition results in complete penetration resistance to powdery mildew in Arabidopsis. Plant Physiol. 161:1433-1444.

Eulgem, T., and Somssich, I. E. 2007. Networks of WRKY transcription factors in defense signaling. Curr. Opin. Plant Biol. 10:366-371.

Felix, G., Duran, J. D., Volko, S., and Boller, T. 1999. Plants have a sensitive perception system for the most conserved domain of bacterial flagellin. Plant J. 18:265-276.

Ger, M.-J., Louh, G.-Y., Lin, Y.-H., Feng, T.-Y., and Huang, H.-E. 2014. Ectopic expressed sweet pepper ferredoxin PFLP enhances disease resistance to Pectobacterium carotovorum subsp. carotovorum affected by harpin and protease-mediated hypersensitive response in Arabidopsis. Mol. Plant Pathol. 15:892-906.

Göhre, V., Jones, A. M., Sklenář, J., Robatzek, S., and Weber, A. P. 2012. Molecular crosstalk between PAMP-triggered immunity and photosynthesis. Mol. Plant-Microbe Interact. 25:1083-1092.

Gómez-Gómez, L., and Boller, T. 2002. Flagellin perception: A paradigm for innate immunity. Trends Plant Sci. 7:251-256.

Guan, X., Buchholz, G., and Nick, P. 2013. The cytoskeleton is disrupted by the bacterial effector HrpZ, but not by the bacterial PAMP flg22, in tobacco BY-2 cells. J. Exp. Bot. 64:1805-1816.

Gust, A. A., Biswas, R., Lenz, H. D., Rauhut, T., Ranf, S., Kemmerling, B., Götz, F., Glawischnig, E., Lee, J., Felix, G., and Nürnberger, T. 2007. Bacteria-derived peptidoglycans constitute pathogen-associated molecular patterns triggering innate immunity in Arabidopsis. J. Biol. Chem. 282: 32338-32348

Hauben, L., Moore, E. R. B., Vauterin, L., Steenacker, M., Mergaert, J., Verdonck, L., and Swings, J. 1998. Phylogenetic position of phytopathogens within Enterobacteriaceae. Syst. Appl. Microbiol. 21:384-397.

Huang, H.-E., Ger, M.-J., Yip, M.-K., Chen, C.-Y., Pandeya, A.-K., and Feng, T.-Y. 2004. A hypersensitive response was induced by virulent bacteria in transgenic tobacco plants overexpressing a plant ferredoxin-like protein (PFLP). Physiol. Mol. Plant Pathol. 64:103-110.

Huang, H.-E., Liu, C.-A., Lee, M.-J., Kuo, C.-G., Chen, H.-M., Ger, M.-J., Tsai, Y.-C., Chen, Y.-R., Lin, M.-K., and Feng, T.-Y. 2007. Resistance enhancement of transgenic tomato to bacterial pathogens by the heterologous expression of sweet pepper ferredoxin-I protein. Phytopathology 97:900-906.

Jones, J. D. G., and Dangl, J. L. 2006. The plant immune system. Nature 444: 323-329.

Kannan, P., Pandey, D., Gupta, A. K., Punetha, H., Taj, G., and Kumar, A. 2012. Expression analysis of MAP2K9 and MAPK6 during pathogenesis of Alternaria blight in Arabidopsis thaliana ecotype Columbia. Mol. Biol. Rep. 39:4439-4444.

Liau, C.-H., Lu, J.-C., Prasad, V., Hsiao, H.-H., You, S.-J., Lee, J.-T., Yang, N.-S., Huang, H.-E., Feng, T.-Y., Chen, W.-H., and Chan, M.-T. 2003. The sweet pepper ferredoxin-like protein ( $p f l p$ ) conferred resistance against soft rot disease in Oncidium orchid. Transgenic Res. 12:329-336.

Lin, Y.-H., Huang, H.-E., Chen, Y.-R., Liao, P.-L., Chen, C.-L., and Feng, T. Y. 2011. C-terminal region of plant ferredoxin-like protein is required to enhance resistance to bacterial disease in Arabidopsis thaliana. Phytopathology 101:741-749.

Lin, Y.-H., Huang, H.-E., Wu, F.-S., Ger, M.-J., Liao, P.-L., Chen, Y.-R., Tzeng, K.-C., and Feng, T.-Y. 2010. Plant ferredoxin-like protein (PFLP) 
outside chloroplast in Arabidopsis enhances disease resistance against bacterial pathogens. Plant Sci. 179:450-458.

Luna, E., Pastor, V., Robert, J., Flors, V., Mauch-Mani, B., and Ton, J. 2011. Callose deposition: A multifaceted plant defense response. Mol. PlantMicrobe Interact. 24:183-193.

Ma, X., Xu, G., He, P., and Shan, L. 2016. SERKing coreceptors for receptors. Trends Plant Sci. 21:1017-1033.

Monaghan, J., and Zipfel, C. 2012. Plant pattern recognition receptor complexes at the plasma membrane. Curr. Opin. Plant Biol. 15:349-357.

Muthamilarasan, M., and Prasad, M. 2013. Plant innate immunity: An updated insight into defense mechanism. J. Biosci. 38:433-449.

Namukwaya, B., Tripathi, L., Tripathi, J. N., Arinaitwe, G., Mukasa, S. B., and Tushemereirwe, W. K. 2012. Transgenic banana expressing pflp gene confers enhanced resistance to Xanthomonas wilt disease. Transgenic Res. 21:855-865.

Nicaise, V., Roux, M., and Zipfel, C. 2009. Recent advances in PAMPtriggered immunity against bacteria: Pattern recognition receptors watch over and raise the alarm. Plant Physiol. 150:1638-1647.

Oh, C.-S., and Beer, S. V. 2005. Molecular genetics of Erwinia amylovora involved in the development of fire blight. FEMS Microbiol. Lett. 253:185-192.

Panstruga, R., Parker, J. E., and Schulze-Lefert, P. 2009. SnapShot: Plant immune response pathways. Cell 136:978-978.e2.

Pérombelon, M. C. M., and Kelman, A. 1980. Ecology of the soft rot Erwinias. Annu. Rev. Phytopathol. 18:361-387.

Pieterse, C. M. J., Leon-Reyes, A., Van der Ent, S., and Van Wees, S. C. M. 2009. Networking by small-molecule hormones in plant immunity. Nat. Chem. Biol. 5:308-316.
Postel, S., and Kemmerling, B. 2009. Plant systems for recognition of pathogen-associated molecular patterns. Semin. Cell Dev. Biol. 20: 1025-1031.

Rasband, W. S. 1997-2016. ImageJ. Online publication. U. S. National Institutes of Health, Bethesda, MD, USA. https://imagej.nih.gov/ij/

Segonzac, C., and Zipfel, C. 2011. Activation of plant pattern-recognition receptors by bacteria. Curr. Opin. Microbiol. 14:54-61.

Su, Y.-H., Hong, C.-Y., and Lin, Y.-H. 2014. Plant ferredoxin-like protein enhances resistance to bacterial soft rot disease through PAMP-triggered immunity in Arabidopsis thaliana. Eur. J. Plant Pathol. 140:377-384.

Tang, K. X., Sun, X. F., Hu, Q. N., Wu, A. Z., Lin, C. H., Lin, H.-J., Twyman, R. M., Christou, P., and Feng, T.-Y. 2001. Transgenic rice plants expressing the ferredoxin-like protein (AP1) from sweet pepper show enhanced resistance to Xanthomonas oryzae pv. oryzae. Plant Sci. 160:1035-1042.

Torres, M. A. 2010. ROS in biotic interactions. Physiol. Plant. 138:414-429.

Yip, M.-K., Huang, H.-E., Ger, M.-J., Chiu, S.-H., Tsai, Y.-C., Lin, C.-I., and Feng, T.-Y. 2007. Production of soft rot resistant calla lily by expressing a ferredoxin-like protein gene ( $p f l p)$ in transgenic plants. Plant Cell Rep. 26: 449-457.

Zhang, J., and Zhou, J.-M. 2010. Plant immunity triggered by microbial molecular signatures. Mol. Plant 3:783-793.

Zipfel, C. 2008. Pattern-recognition receptors in plant innate immunity. Curr. Opin. Immunol. 20:10-16.

Zipfel, C., and Robatzek, S. 2010. Pathogen-associated molecular patterntriggered immunity: Veni, Vidi...? Plant Physiol. 154:551-554. 